\title{
The Influence of Sharia Supervisory Board, Leverage, and Equitable Distribution Ratio on Earnings Management Practices in Islamic Banking
}

\author{
Bagas Brian Pratama*, Muhammad Muwidha, Ari Kamayanti \\ Politeknik Negeri Malang \\ Malang, Indonesia \\ *Bagas.brian.bb@gmail.com, Muhammad.muwidha@polinema.ac.id, Kamayanti.ari@gmail.com
}

\begin{abstract}
This study aims to explore the influence of the Sharia Supervisory Board, Leverage and Equitable Distribution Ratio on earnings management practices at Islamic Banking in Indonesia. The population in this study consisted of 15 Islamic Banking companies registered under the Financial Services Authority (OJK) during 2011-2018. The acquisition of a sample of 8 companies were determined through purposive sampling. The data were collected using the documentation method obtained from the company's published annual reports. The data were then analyzed using the Multiple Linear Regression analysis technique which was processed using of the SPSS.25 program. The results showed that simultaneously all the independent variables tested had a significant effect on the earnings management with Adjusted $R$ Square value of $25.3 \%$. Meanwhile, partially the Sharia Supervisory Board had no significant effect on earnings management, while Leverage and Equitable Distribution Ratio had a significant negative effect on earnings management. The significant influence of Leverage and Equitable Distribution Ratio proves that managers have a high consideration of the company's financial ratios in determining company policy. While the insignificant results from the other variables show the weak oversight function of the Sharia Supervisory Board in Islamic Banking.
\end{abstract}

Keywords-earning management, sharia supervisory board, leverage, equitable distribution ratio

\section{INTRODUCTION}

In the business world, every behavior of an individual is always viewed as an economic goal. Moreover, investors tend to have great attention to the final value of the company's earnings by not having a deeper understanding of the company's operating process [1]. Investors tend to minimize the level of risk so that their only target is the final outcome of the profit. This is in line with the definition of agency theory. Agency theory is a condition that occurs in a company where the management, known as the agent and the owner as the principal, builds a cooperation contract called the "nexus of contract". This cooperation contract contains agreements - an agreement that explains the management of the company must work optimally to provide maximum satisfaction, such as high profits for the investor or the owner [2]. In these conditions, the company management makes a policy to maintain the value of earnings in the eyes of investors by implementing earnings management. Unfortunately, this policy often generates biased information and tends to deceive which makes it "dangerous" for whoever taking advantage of financial statements [3].

On the other hand, at a Sharia Commercial Bank, all of its business activities should be based on the principles of sharia which are regulated in the Qur'an, Hadith and other sources permitted in the Islamic religious law by upholding the principles of justice, honesty and benefit for people [4]. Meanwhile, the practice of earnings management is actually one of the business practices prohibited in sharia law because it contains elements of Fraud and Gharar [5]. Therefore, it should be ideal for Islamic Commercial Banks not to practice earnings management. However, unfortunately, many previous studies have indicated that several Islamic Commercial Banks are still practicing earnings management. Thus, this research will examine whether there is a practice of earnings management and its relationship with the two Leverage which represents the conventional side of the company and the Equitable Distribution Ratio which represents the sharia side of the company. These two variables are two factors that should have an influence on the management of Islamic banks in conducting earnings management practices.

This research is the development and a renewal from previous studies. Unlike previous studies that measured earnings management using the accrual method formulated by Jones [6], in this study, the measurement of earnings management will use the Stubben [7] formula, which is one of the newest measurement methods for earnings management and is proven to be more effective. It is better at identifying earnings management than Jones's accrual method [8].

\section{LITERATURE REVIEW}

\section{A. Earnings Management}

Earnings management is a manager's policy on selecting accounting methods to achieve specific goals [9]. Earnings management is a deliberate process with financial accounting 
standards limits to direct earnings reporting at a certain level to fulfill the expectation of the company management [10].

Meanwhile, in Islamic sharia law, earnings management is prohibited because it provides harm to one of the parties who are doing muammalah (transaction or having a deal). Whereas in Islamic law all parties who transact must be mutually Ridho (full of consent) and mutually benefit all parties. Earnings management is also a form of gharar (dangerous risk) because of the unclear and biased information it generates. That is why it is haram (prohibited) in Islamic law [5]. In line with the hadith narrated by Muslim "Indeed the Prophet S.A.W prohibited gharar (speculative and uncertain) transaction". Therefore, this earnings management practice should be left put in sharia business operations.

\section{B. Leverage}

The leverage ratio measures how much a company is financed with debt. Too excessive debt will put the company at risk because the company would have bigger possibility to fall into the extreme leverage category. When the company is trapped in a high level of debt, it would be difficult to pay off the debt [2]. By increasing the level of leverage, the level of uncertainty of the return will be higher, and at the same time, it will also increase the amount of return that the company receives [11]. Thus, leverage is a company's financial ratio that shows how much the company is able to utilize the resources to fulfill its future obligations.

When the leverage ratio is low, this indicates that the company is very risky for not being able to fulfill their obligations. Therefore, the company management must reduce the financial risk as much as possible in order to satisfy the owners of capital. The alternative for this is to increase company profits with earnings management techniques. This is in line with the research results of Yofi Prima and Elly Suryani [12], they found that leverage has a significant effect on earnings management practices.

H2: Leverage has a significant effect on earnings management practices at Islamic Commercial Banks.

\section{Equitable Distribution Ratio}

Hameed et al, in their research, has developed an index that aims to measure the financial performance of Islamic financial institutions by including spiritual elements in the measurement of the financial performance of sharia-based companies [13]. This index is called the Islamicity index. The Islamicity index could evaluate financial aspects, and also the principles of justice, halalness and purification (takziyah) carried out by Islamic financial institutions.

One of the indicators is the Equitable Distribution Ratio (EDR). This ratio measures how much a company can distribute its income fairly to all company stakeholders [14].

Earnings management is a form of calculation that focuses on profits only by ignoring the losses incurred by other stakeholders on the implementation of this earnings management. This certainly violates the principles and values of justice and benefit that should be upheld by the Islamic banking management. In measuring the values of justice and benefit, investors can use the Equitable Distribution Ratio [14].

H2: Equitable Distribution Ratio has a significant effect on earnings management practices at Islamic Commercial Banks.

\section{Sharia Supervisory Board}

The sharia supervisory board is an agency in charge of overseeing the implementation of DSN decisions in Islamic financial institutions. DPS is appointed and dismissed at a sharia financial institution through the GMS after receiving a recommendation from DSN. According to Law no. 21 of 2008 concerning Islamic banking or Islamic financial institutions, every Islamic bank or Islamic financial institution in Indonesia, Sharia Commercial Banks (BUS) and Sharia Business Units (UUS), are required to form a Sharia Supervisory Board, which is generally tasked with providing advice to directors, as well as supervising bank activities according to the sharia principles [15]. According to Nasution et al., the sharia supervisory board is tasked with overseeing the operations of the bank and its products to stay in line with sharia law. In this study, the value of the Sharia Supervisory Board is calculated from the number of meetings held by the company's SSB for one year [16].

With the Sharia Supervisory Board (DPS), the practice of earning management at Islamic Commercial Banks in Indonesia should be reduced or even stopped completely. This is in line with research from Ben Othman who found that the Sharia Supervisory Board has a significant influence on earnings management practices in Islamic Banks [17].

H3: Sharia Supervisory Board has a negative effect on earnings management practices in Islamic commercial banks.

\section{RESEARCH METHODS}

This research is a quantitative research. The method used is collecting documentation and literacy studies from financial reports and company annual reports. The population in this study were all Sharia Commercial Bank companies in Indonesia, with a sample of 8 companies. The sample selection used purposive sampling technique.

\section{RESULTS AND DISCUSSION}

The research sample consisted of 8 companies with the following criteria: (1) The companies are Sharia Commercial Banks that have been registered with the Financial Services Authority (OJK) starting from 2011-2018 (2) The companies have consistently published Annual Reports from 2011- 2018. (3) The company did not carry out significant economic activities such as mergers, liquidations and other activities that caused radical changes in company profits during 2011-2018. (4) Companies that made consecutive profits during the study period. 
Based on the test results from descriptive statistical tests, classical assumption tests and multiple regression analysis tests, the following results were obtained (Table 1):

TABLE I. DESCRIPTIVE STATISTICS

\begin{tabular}{|c|l|l|l|l|l|}
\hline & \multicolumn{1}{|c|}{ N } & \multicolumn{1}{|c|}{ Min } & \multicolumn{1}{|c|}{ Max } & \multicolumn{1}{|c|}{ Mean } & Std. Dev \\
\hline $\boldsymbol{M L}$ & 64 & 0.002 & 4.698 & 0.753 & 0.957 \\
\hline $\boldsymbol{D P S}$ & 64 & 6 & 36 & 15.43 & 7.143 \\
\hline $\boldsymbol{L} \boldsymbol{e}$ & 64 & 0.744 & 0.942 & 0.879 & 0.045 \\
\hline $\boldsymbol{E D R}$ & 64 & 0.080 & 0.617 & 0.226 & 0.110 \\
\hline
\end{tabular}

TABLE II. NORMALITY TEST RESULTS

\begin{tabular}{|c|l|}
\hline \multicolumn{2}{|c|}{ Unstandardized Residual } \\
\hline $\boldsymbol{N}$ & 64 \\
\hline Statistic Test & 0,47 \\
\hline Asymp. Sig. (2-tailed) & 0,200 \\
\hline
\end{tabular}

In the Kolmogrof-Sminorv test, data is said to be normally distributed if the significance is more than 0.05. If the significance result is less than 0.05 , the data is not normally distributed. Thus, based on Table 2, it shows that the significance value is 0.200 which indicates that the data in this study have been normally distributed.

TABLE III. HETEROSCEDASTICITY TEST RESUlTS

\begin{tabular}{|c|c|}
\hline Model & Sig. \\
\hline Constant & 0.350 \\
\hline $\boldsymbol{D P S}$ & 0.211 \\
\hline $\boldsymbol{L} \boldsymbol{E}$ & 0.831 \\
\hline $\boldsymbol{R}$ & 0.632 \\
\hline \multicolumn{2}{|c|}{ Dependent variable: Abs_Res1 } \\
\hline
\end{tabular}

Table 3 shows that all variables have a significance valueof more than 0.05 , which means that the research data passed the heteroscedasticity test.

TABLE IV. AUTOCORRELATION TEST RESUlTS

\begin{tabular}{|c|l|}
\hline \multicolumn{2}{|c|}{ Unstandardized Residual } \\
\hline Total Cases & 64 \\
\hline Number of Runs & 35 \\
\hline Z & 0,504 \\
\hline Asymp. Sig. (2-tailed) & 0,614 \\
\hline
\end{tabular}

Table 4 shows the results of the autocorrelation test using the run test. It can be concluded that the regression model in this study does not have autocorrelation symptoms because the test results show that the significance value is 0.614 , much greater than 0.05 .

TABLE V. Multicolonierity Test Results

\begin{tabular}{|c|c|c|}
\hline & Tolerance & VIF \\
\hline $\boldsymbol{D P S}$ & 0.983 & 1.02 \\
\hline $\boldsymbol{L} \boldsymbol{E D R}$ & 0.941 & 1.07 \\
\hline \multicolumn{2}{|c|}{ Dependent variable: ML } \\
\hline
\end{tabular}

Based on Table 5, the results of the heteroscedasticity test concluded that the regression model in this study does not have any symptoms of heteroscedasticity because the test results show that the tolerance value $\geq 0.01$ which is equal to 1,000 and the VIF value $\leq 10$ which is equal to 1,000 .

TABLE VI. MULTIPLE REGRESSION RESUlts

\begin{tabular}{|l|l|}
\hline \multicolumn{1}{|c|}{ Model } & \multicolumn{1}{c|}{$\boldsymbol{\beta}$} \\
\hline Constant & 1,445 \\
\hline DPS & 1,463 \\
\hline Le & $-1,131$ \\
\hline EDR & $-1,149$ \\
\hline
\end{tabular}

The results of multiple linear regression analysis based on Table 6 show the following equation:

$$
\mathrm{ML}=1,445+1,463 \mathrm{DPS}-1,131 \mathrm{Le}-1,149 \mathrm{EDR}+\mathrm{e}
$$

A constant of 1.445 indicates that if Le, DPS, and EDR are constant, the amount of earnings management is 1.445 . In the DPS variable, the regression coefficient value is 1.436 . This means that every increase of 1 in DPS will increase the value of earnings management by 1.436 . The positive value on this regression coefficient indicates that the increase in the DPS variable will be directly proportional to the increase in the earnings management value. Le has a regression coefficient of $-1,131$. This explains that when Le increases by 1 , the earnings management will decrease by 1.131 , if other independent variables have a fixed value. The regression coefficient is negative, which means that the relationship between earnings management and Le is negative, so that an increase in the company's leverage will reduce the value of the company's earnings management. The regression coefficient value of the EDR variable is -1.149 . This value implies that there is an inversely proportional relationship between EDR and earnings management, where every EDR value increaseby 1 will make a decrease of 1.149 in the company's earnings management.

TABLE VII. T TEST RESUlt (PARTIAL)

\begin{tabular}{|l|l|l|}
\hline \multicolumn{1}{|c|}{ Model } & \multicolumn{1}{c|}{ t } & Sig. \\
\hline Constant & 4.205 & 0.000 \\
\hline DPS & 1.271 & 0.209 \\
\hline Le & -3.004 & 0.004 \\
\hline EDR & -3.373 & 0.001 \\
\hline
\end{tabular}

Dependent variable: $\mathrm{ML}$

Based on the results of the $t$ test in table 7 , several conclusions were drawn. The Le and EDR give partially negative effect on earnings management because the two variables have a significance level below the error level of

0.05 with a significance level of 0.004 and 0.001 respectively. Meanwhile, DPS does not show a partial influence on earnings management because the level of significance of the two variables is higher than the error level of 0.05 with a significance level of 0.269 .

These results are consistent with the research of Fengju et al. [18] which states that there is a negative relationship 
between leverage and earnings management. It is also in line with the measurement results of the Sharia Supervisory Board. Octaviani et al [19] also found that, based on the results of research from Maisaroh [20], that there is a significant positive relationship between the Equitable Distribution Ratio and the company's profitability, while Profitability has a significant negative effect on earnings management based on the research results of Purnama [21] and Saputra et al., [22]. Thus, it can be concluded that the results of this study are in line and indirectly consistent with previous studies.

Meanwhile, Hameed et al., in another study explained that stakeholders in Islamic companies have different special perspectives in viewing Islamic and conventional companies in general [13]. In the stakeholder perspective, the objective of Islamic banks is to maximize profits, contribute to social welfare, reduce poverty and promote Islamic values in the economic life of society. Therefore, the most likely implication of management from the existence of a significant negative relationship between the Equitable Distribution Ratio and earnings management in this study is the increased ability of companies to distribute income, and shifting the focus from the earnings management, thus causing less desire for manipulative action toward the earnings management in the company's financial statements.

TABLE VIII. F TEST RESUlts AND THE COEFFICIENT OF DETERMINATION

\begin{tabular}{|l|l|l|l|}
\hline \multicolumn{4}{|c|}{ Statistical Test F } \\
\hline F Value & 6,271 & Sig. & 0,000 \\
\hline \multicolumn{4}{|c|}{ Coefficient of Determination } \\
\hline R2 & 0,298 & & \\
\hline Adj. R2 & 0,251 & & \\
\hline
\end{tabular}

Based on the results of the calculations shown in Table 8 above, it shows that the significance value of 0.000 indicates that the Leverage, DPS and EDR variables simultaneously influence earnings management practices at Islamic Commercial Banks. In line with these results, the calculation of the calculated $\mathrm{F}$ value shows a value greater than $\mathrm{F}$ table $(4,60)$ where $6.271>2.53 \ldots$ this strengthens the conclusion that all the independent variables in this study are proven to influence the dependent variable simultaneously. Meanwhile, the value of Adj. R2 on the coefficient of determination shows how much all these independent variables can project the value of the measured dependent variable. Based on the test results presented in the table image above, it shows that the coefficient of determination (R2) shown in the Adjusted R Square value is 0.251 or $25.1 \%$. This also means that in the regression equation model, earnings management as the dependent variable could be proxies by Leverage, the Independent Commissioner Board, the Sharia Supervisory Board and the Equitable Distribution Ratio as an independent variable of $25.1 \%$, while the remaining $74.9 \%$ is influenced by other factors not included in the regression model of this study.

The results of this study illustrate that the practice of compliance in implementing sharia law in the business world is still very small and is influenced by many factors. It is in line with the results of research from Waluyo which explains that the supervision system for sharia compliance is not optimal [23]. Whereas every action in the sharia business should stick to the teachings of the Al-Quran and Sunnah without any intervention from other factors that violate the decrees of Allah SWT and Rasulullah SAW. In Surat Al- Baqarah / 2: 168 Allah SWT. emphasized "O mankind, eat from whatever is on earth [that is] lawful and good and do not follow the footsteps of Satan. Indeed, he is to you a clear enemy."

\section{CONCLUSION AND SUGGESTION}

The results of this study concluded that the increase or decrease in the value of the Independent Commissioner Board and Sharia Supervisory Board will not have a significant effect on changes in the value of Earnings management at BUS. Meanwhile, an increase in the value of leverage will cause a decrease in the value of earnings management. The Equitable Distribution Ratio value is also inversely proportional to the value of earnings management at Islamic Commercial Banks.

These findings indicate a lack of supervisory function of the Independent Commissioner Board and the Sharia Supervisory Board. In short, the two boards do not have a significant contribution in controlling the management activities of Islamic companies in conducting earnings management practices.

On the other hand, financial ratios remain a big motivation for company management to take economic policies for the company. This is certainly plays a bigger goal for sharia-based companies to always evaluate themselves and maintain management compliance in implementing sharia business law in any circumstances. This cannot be separated from the basis for the establishment of a sharia company, where a shariabased company should have a broader business motive than just profits, but also pay attention on how the company can make a major contribution to the benefit for the people.

For the sake of improving further research and considering the dynamic development of the business world in the future, further research on earnings management is expected to use the latest formulas in measuring earnings management. Thus, the projection of the earnings management value would be more accurate and display more relevant results. In addition, the performance measurement of the DKI and DPS independent variables could use a more complex measure so that it can describe the performance of the board better than the percentage of DKI and the number of DPS meetings in this study.

\section{REFERENCES}

[1] I. Nurachman, "Analisis Faktor-Faktor Yang Mempengaruhi Praktik Perataan Laba (Income Smoothing)." Universitas Pendidikan Indonesia 2014.

[2] I. Fahmi, “Analisis Laporan Keuangan.” Bandung: Alfabeta, 2011.

[3] D. Kurniawansyah, "Apakah Manajemen Laba Termasuk Kecurangan?: Analisis Literatur," J. Ris. Akunt. Dan Bisnis Airlangga, vol. 3, no. 1, 2018 
[4] Z. Saidi, Tidak syar'inya bank syariah di Indonesia dan jalan keluarnya menuju muamalat. Delokomotif, 2010.

[5] A.Y. Marzuqi and A.B. Latif, "Manajemen Laba Dalam Tinjauan Etika Bisnis Islam," J. Din. Ekon. Bisnis, vol. 7, no. 1, 2010.

[6] J.J. Jones, "Earnings Management during Import Relief Investigations," J. Account. Res., vol. 29, no. 2, pp. 193-228, 1991.

[7] S.R. Stubben, "Discretionary Revenues as a Measure of Earnings Management," Account. Rev., vol. 85, no. 2, pp. 695-717, 2010.

[8] H. Yusnita and M. Ak, "Revenue Model Dan Conditional Revenue Model Untuk Mendeteksi Manajemen Laba," J. Akunt. dan Bisnis Krisnadwipayana, vol. 6, no. 2, 2019.

[9] D. Suhardjanto, A. Dewi, E. Rahmawati, and M. Firazonia, "Peran Corporate Governance Dalam Praktik Risk Disclosure Pada Perbankan Indonesia," J. Akunt. dan Audit., vol. 9, no. 1, pp. 16-30, 2012.

[10] N. Adibah, T.R. Nugroho, and M.B. Ilmiddaviq, "Pengaruh Manajemen Laba Pada Return Saham Dengan Kualitas Audit Dan Kepemilikan Manajerial Sebagai Variabel Pemoderasi (Studi Empiris Pada Perusahaan Perbankan Yang Terdaftar Di Bursa Efek Indonesia Periode Tahun 2017-2019)." Universitas Islam Majapahit, 2020.

[11] E. Wijayanto and A.N. Putri, "Analisis Pengaruh Rasio Likuiditas, Rasio Leverage, Rasio Profitabilitas Dan Kepemilikan Manajerial Terhadap Kebijakan Dividen,” J. Aktual Akunt. Keuang. Bisnis Terap., vol. 1, no. 2, 2018.

[12] Y.P. Agustia and E. Suryani, "Pengaruh Ukuran Perusahaan, Umur Perusahaan, Leverage, Dan Profitabilitas Terhadap Manajemen Laba (Studi Pada Perusahaan Pertambangan Yang Terdaftar Di Bursa Efek Indonesia Periode 2014-2016)," J. Aset (Akuntansi Riset), vol. 10, no. 1, pp. 71-82, 2018.

[13] S. Hameed, A. Wirman, B. Alrazi, M. Nazli, and S. Pramono, "Alternative Disclosure and Performance Measures for Islamic Banks," in Second Conference on Administrative Sciences: Meeting the Challenges of the Globalization Age, King Fahd University of Petroleum \& Minerals, Dhahran, Saudi Arabia, 2004, pp. 19-21.

[14] S. Aisyah and A. Hardianto, "Analisa Kinerja Perbankan Syariah Di Indonesia Dengan Menggunakan Pendekatan Islamicity Performance
Index Dan Islamic Corporate Governance," J. Ilmu Syariah, vol. 14, no. $2,2018$.

[15] F.I. NILAMSARI and S. WAHYUDI, "Analisis Pengaruh Kinerja Keuangan, Dewan Pengawas Syariah, Dewan Komisaris, Komisaris Independen, Dan Ukuran Bank Terhadap Corporate Social Responsibility (Studi Kasus Pada Perusahaan Perbankan Syariah Indonesia Tahun 2011-2015).” Fakultas Ekonomika dan Bisnis, 2017.

[16] A.W. Nasution and M. Fatira, "Analisis Faktor Kesadaran Literasi Keuangan Syariah Mahasiswa Keuangan Dan Perbankan Syariah," Jurnal, vol. 7, pp. 40-63, 2019.

[17] H. Mersni and H. Ben Othman, "The Impact of Corporate Governance Mechanisms on Earnings Management in Islamic Banks in the Middle East Region," J. Islam. Account. Bus. Res., 2016.

[18] X. Fengju, R. Yari Fard, L. Ghassab Maher, and N. Akhteghan, "The Relationship between Financial Leverage and Profitability with an Emphasis on Income Smoothing in Iran's Capital Market," Eur. Online J. Nat. Soc. Sci., vol. 2, no. 3 (s), p. pp-156, 2013.

[19] S. Octaviani and D. Komalasari, "Pengaruh Likuiditas, Profitabilitas, Dan Solvabilitas Terhadap Harga Saham,” J. Akunt. Kaji. Ilm. Akunt., vol. 4, no. 1, 2017.

[20] S. Maisaroh, "Pengaruh Intellectual Capital Dan Islamicity Performance Index Terhadap Profitability Perbankan Syariah Indonesia." Universitas Islam Negeri Maulana Malik Ibrahim, 2015.

[21] A.R.N. Purnama, "Analisis Pengaruh Profitabilitas, Likuiditas Terhadap Kebijakan Dividen Kas (Studi Pada Perusahaan Industri Otomotif Dan Komponennya Yang Listing Di Bursa Efek Indonesia Periode 20062016)." Universitas Brawijaya, 2017.

[22] A. Saputra, M. Arfan, and M. Saputra, "Pengaruh Capital Adequacy Ratio, Net Interest Margin, Loan To Deposit Ratio Dan Non Performing Loan Terhadap Profitabilitas Bank Umum Non Devisa Di Indonesia Periode 2014-2016," J. Perspekt. Ekon. Darussalam, vol. 4, no. 2, pp. 199-212, 2018.

[23] A. Waluyo, "Kepatuhan Bank Syariah Terhadap Fatwa Dewan Syariah Nasional Pasca Transformasi Ke Dalam Hukum Positif,” INFERENSI J. Penelit. Sos. Keagamaan, vol. 10, no. 2, pp. 517-538, 2016. 